ACCOUNTING FOR CHANGES IN THE SPANISH WAGE DISTRIBUTION:

THE ROLE OF EMPLOYMENT COMPOSITION EFFECTS

Raquel Carrasco, Juan F. Jimeno

and a carolina ontega

Documentos de Trabajo.

N. 1120

banco mespaña
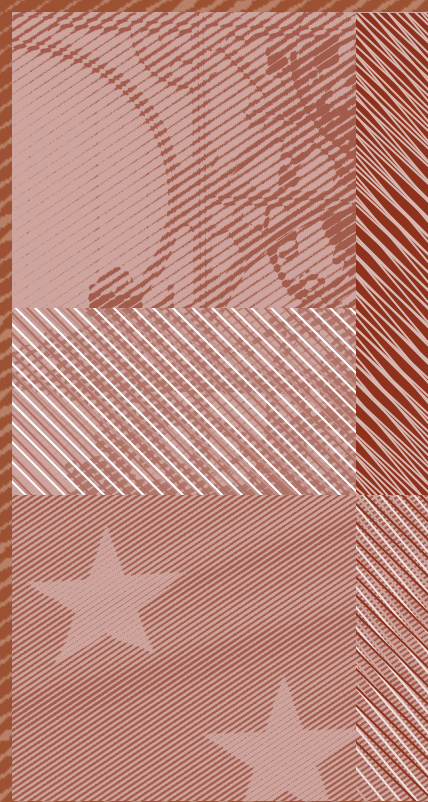
ACCOUNTING FOR CHANGES IN THE SPANISH WAGE DISTRIBUTION:

THE ROLE OF EMPLOYMENT COMPOSITION EFFECTS 


\title{
ACCOUNTING FOR CHANGES IN THE SPANISH WAGE \\ DISTRIBUTION: THE ROLE OF EMPLOYMENT COMPOSITION EFFECTS ${ }^{*}$
}

\author{
Raquel Carrasco \\ UNIVERSIDAD CARLOS III \\ Juan F. Jimeno \\ BANCO DE ESPAÑA
}

A. Carolina Ortega
UNIVERSIDAD NACIONAL DE TUCUMÁN

$\left.{ }^{*}\right)$ We are grateful to Olympia Bover, Elena Martínez-Sanchís and Hipólito Simón for comments on a previous draft of this paper, and to participants at Banco de España and FEDEA seminars for helpful comments. First author acknowledges research funding from the Spanish Ministry of Science and Innovation, Grant No. ECO2009-11165. All remaining errors are our own. 
The Working Paper Series seeks to disseminate original research in economics and finance. All papers have been anonymously refereed. By publishing these papers, the Banco de España aims to contribute to economic analysis and, in particular, to knowledge of the Spanish economy and its international environment.

The opinions and analyses in the Working Paper Series are the responsibility of the authors and, therefore, do not necessarily coincide with those of the Banco de España or the Eurosystem.

The Banco de España disseminates its main reports and most of its publications via the INTERNET at the following website: http://www.bde.es.

Reproduction for educational and non-commercial purposes is permitted provided that the source is acknowledged.

\section{(C) BANCO DE ESPAÑA, Madrid, 2011}

ISSN: 0213-2710 (print)

ISSN: 1579-8666 (on line)

Depósito legal: M. 35896-2011

Unidad de Publicaciones, Banco de España 


\begin{abstract}
Despite a rapid decrease in unemployment and strong GDP and employment growth, real wages barely increased in Spain over the period 1995-2006. An explanation of this lack of growth may rely on employment composition effects derived from structural changes, such as the rise in the weights of employment in the construction and services sectors, the increase in female employment participation, and the arrival of large immigration inflows. Using data from three waves of the Structure of Earnings Survey, we break down observed wage changes into those due to varying worker and job characteristics and variations of the returns to those characteristics. Quantile regressions are used to estimate wage equations at different percentiles and to construct the counterfactual wage distributions that would have been observed had individual and job characteristics remain constant over time. Our main finding is that the lack of growth of Spanish real wages over the period 1995-2006 is mainly due to the decrease of returns to characteristics, specially education and labour market experience, which is more noticeable at the upper deciles of the wage distribution, and not to changes in employment composition, which when taken over a wide set of worker and job characteristics, had positive effects on wages.
\end{abstract}

Keywords: Wage structure, quantile regressions, composition effects.

JEL Codes: J31, J21. 


\section{Resumen}

A pesar de una rápida disminución del desempleo, los salarios reales en España apenas aumentaron durante el periodo 1995-2006. Una posible explicación de este comportamiento se refiere a la importancia de los efectos composición derivados de algunos cambios estructurales, tales como el aumento del peso del empleo en la construcción y en el sector servicios, el incremento de la participación laboral femenina, y la llegada masiva de inmigrantes. Utilizando datos de tres olas de la Encuesta de Estructura Salarial, se descompone la variación salarial observada durante este periodo en dos componentes, el debido a los cambios en las características de los puestos de trabajo y de los trabajadores, y el causado por los cambios en los rendimientos de dichas características. Así, mediante regresiones cuantílicas que estiman ecuaciones de salarios condicionadas a determinados percentiles de la distribución salarial, se construyen las distribuciones contrafactuales que se hubieran observado de haberse mantenido constantes las características de los puestos de trabajo y de los trabajadores. El principal resultado es que la falta de crecimiento de los salarios reales en España durante el periodo 1995-2006 se debe, sobre todo, a la caída de los rendimientos, especialmente de la educación y de la experiencia laboral en los deciles elevados de la distribución salarial, y no tanto a cambios en la composición del empleo que, computados sobre un conjunto amplio de características, tuvieron un efecto global positivo sobre los salarios.

Palabras clave: Estructura salarial, regresión cuantílica, efecto composición.

Códigos JEL: J31, J21. 


\section{Introduction}

During the period 1995-2006 the Spanish economy experienced a long and strong expansion with significant GDP growth and employment creation. However, despite the large increase in labour demand, wage pressures remained subdued, with aggregate real wage decreasing at annual rates of $-0.5 \%$ and $-0.3 \%$ in $1995-2000$ and $2000-2005$, respectively [OECD (2007)]. Another remarkable feature of the evolution of wages in Spain during this period is that the wage distribution was relatively stable, not showing increasing inequality.

Figure 1, which plots the Spanish wage distributions for 1995, 2002 and 2006, shows these two facts. ${ }^{1}$ One is the almost negligible change in the mean of the distribution of real hourly wages. Moreover, the distribution becomes more compressed after 1995, especially for men. ${ }^{2}$ The second is that, if anything, wage inequality seems to have fallen. Overall, inequality, as indicated by the standard deviation of log wages, has decreased slightly in this period (Table 1). As indicated by the ratio of percentiles, this is the result of an increase of inequality in the upper tail of the distribution and a decrease of inequality in the lower tail during the period 1995-2002.

Figure 1. Wage distributions in 1995, 2002 and 2006 (2002 Euros)
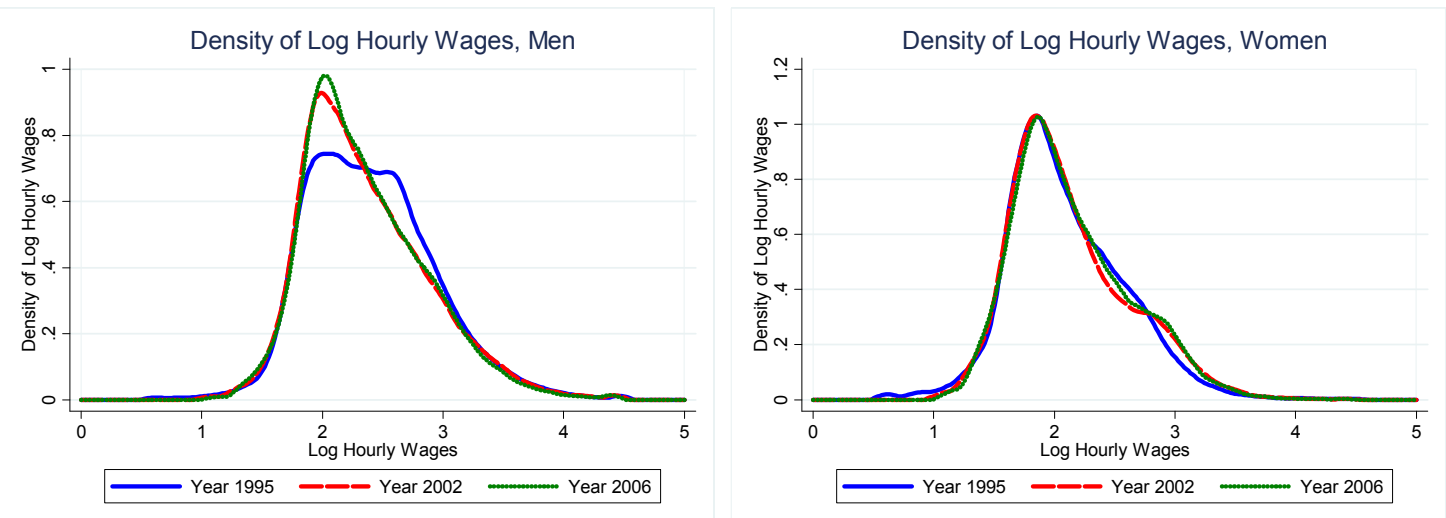

Source: Structure of Earnings Survey (SES).

Note: SES 1995 wave did not cover some non-market sectors (educational, health and social services), so that the density for that year is not strictly comparable to the other two.

1. Wages refer to real hourly wages. In Section 2 below we describe the data source and the construction of the wage variable.

2. This point has been also noted by Izquierdo and Lacuesta (2006) and Pijoan-Mas and Sánchez-Marcos (2010). 
Table 1. Some measures of wage inequality

\begin{tabular}{|rcccccc|}
\hline \multicolumn{5}{c}{ Men } & \multicolumn{3}{c|}{ Women } \\
\hline & SD log w** & P90/P50*** & P50/P10 & SD log w & P90/P50 & P50/P10 \\
\hline 1995 & 0.525 & 1.310 & 1.311 & 0.484 & 1.363 & 1.277 \\
$2002^{*}$ & 0.510 & 1.355 & 1.252 & 0.448 & 1.369 & 1.240 \\
\hline 2002 & 0.518 & 1.355 & 1.264 & 0.490 & 1.406 & 1.271 \\
2006 & 0.502 & 1.342 & 1.255 & 0.483 & 1.394 & 1.279 \\
\hline
\end{tabular}

Source:Structure of Earnings Survey (SES).

Notes: * Figures exclude some non-market sectors (educational, health, and social services) to obtain comparable figures with those for 1995. ** Standard deviation of log real hourly wages. ${ }^{\star \star *}$ Ratio of percentiles.

Any detailed and thorough analysis of wage changes over this period needs to take into account of employment composition effects, derived from significant changes both in labour supply and in labour demand. As far as labour supply is concerned, this is a period of huge immigration inflows [see Carrasco, Jimeno and Ortega (2008)], increasing female participation, on a trend initiated in the 1980s [see Bover and Arellano (1995)], and educational upgrading of the labour force [see Lacuesta, Puente and Cuadrado (2011)]. As for labour demand, immigrant assimilation took place through changes in the sectoral composition of output, with low-paid jobs increasing their weight in total employment [see González and Ortega (2009)]. Additionally, low real interest rates and lax credit conditions, together with some changes in the regulation of urban land, contributed to engineer a boom in the construction sector [see Arce, Campa and Gavilán (2009)].

Without a proper control of these employment composition effects, it is difficult to reveal changes in the wage structure. The main goal of this paper is precisely to account for these changes, by breaking them down into changes in worker and job characteristics and into changes in the returns to those characteristics. To accomplish it, we use the Machado and Mata (2005) technique to estimate actual and counterfactual distributions using a series of linear quantile regressions. Thus, using data from the Spanish Structure of Earnings Survey, we construct the counterfactual wage distributions that provide the wages that would have been observed in 2006 and 2002 had individual and job characteristics remain as those of 2002 and 1995, respectively. ${ }^{3}$ The estimations of wage gaps and of the contributions of individual and job characteristics to wage changes come from quantile wage regressions under two alternative specifications, one in which only workers' age and years of schooling determine wages, and another in which some job characteristics, such as tenure, occupation and sector of activity, are also included in the wage equations. ${ }^{4}$ Our main finding is that the lack of growth of Spanish real wages over the period 1995-2006 is mainly due to the decrease of returns to characteristics, specially education and labour market experience, which is more noticeable at the upper deciles of the wage distribution, and not to changes in employment composition, which taken over the full set of worker and worker/job characteristics, had overall positive effects on wages.

3. Applications and extensions of the Machado and Mata (2005) methodology include Albrecht et al. (2003 and 2010), Melly (2005), Arulampalam et al. (2007) or Martínez-Sanchís et al. (2011).

4. Christopoulou, Jimeno and Lamo (2009) perform a similar analysis, breaking down changes in wage distributions in nine European countries over the 1995-2002 period, and relating these changes and their components to macroeconomic trends and institutional changes observed in these countries. 
The paper is structured as follows. Section 2 describes the data used for the analysis. Section 3 documents the main changes in the Spanish workforce composition between 1995 and 2006 and presents wage gaps among some relevant individual and job characteristics. Section 4 presents the quantile wage regressions underpinning the construction of the counterfactual wage distributions, and describes the decomposition method used to breaking down observed wage changes into composition effects and changes in relative returns to some individual and job characteristics. Section 5 comments on the results. Finally, Section 6 contains some concluding remarks. 
We use data from the Spanish Structure of Earnings Survey (SES henceforth), of which three waves (1995, 2002 and 2006) are available. This survey consists in a random sample of workers from firms of at least 10 employees in the manufacturing, construction and services sectors. ${ }^{5}$ The sampling takes place in two stages. In the first stage, firms are randomly selected from the Social Security General Register of Payments records, which are stratified by region and firm size. In the second stage, a sample of workers from each of the selected firms is also randomly selected. The survey collects detailed information on workers' wages, as well as on workers' personal characteristics, such as gender, age, educational attainment, and nationality, ${ }^{6}$ and job characteristics, including tenure, sector, occupation, contract and job type, firm size and ownership, and region.

We compute workers' real hourly wage by taking the ratio of the gross annual salary, including extraordinary payments, to the total number of hours actually worked, and converting it into 2002 Euros. In 2002 the coverage of the survey was extended to some non-market services (educational, health, and social services sectors) which were not included in the 1995 wave of the survey. For comparisons between these two dates, these sectors are dropped out in order to obtain a homogenous sample. As for the 2002-2006 comparison, we use the full sample, including also non-market sectors.

The sample descriptive statistics (see Table A1) show a decrease of the mean of the log real wage for men, while for women there is a slightly increase. Moreover, the standard deviation of log-wages remained also almost constant along the period considered. Table 2 presents the wage evolution of the $10^{\text {th }}, 50^{\text {th }}$, and $90^{\text {th }}$ percentiles of the wage distribution. It shows a slight increase along time for the lowest percentile, and a slight decrease for the median and the $90^{\text {th }}$ percentile of the wage distribution.

Table 2. Wage evolution of the $10^{\text {th }}, 50^{\text {th }}$, and $90^{\text {th }}$ Percentiles

\begin{tabular}{lcccc}
\hline & Year & $\mathbf{1 0}^{\text {th }}$ & $\mathbf{5 0}^{\text {th }}$ & $\mathbf{9 0}^{\text {th }}$ \\
\hline \multirow{4}{*}{ Men } & $\mathbf{1 9 9 5}$ & 1.797 & 2.357 & 3.088 \\
& $\mathbf{2 0 0 2}^{*}$ & 1.795 & 2.246 & 3.043 \\
& $\mathbf{2 0 0 2}$ & 1.794 & 2.268 & 3.072 \\
& $\mathbf{2 0 0 6}$ & 1.804 & 2.242 & 3.008 \\
\hline \multirow{4}{*}{ Women } & & & & \\
& $\mathbf{1 9 9 5}$ & 1.580 & 2.018 & 2.751 \\
& $\mathbf{2 0 0 2}$ & 1.582 & 1.962 & 2.686 \\
& $\mathbf{2 0 0 2}$ & 1.593 & 2.025 & 2.846 \\
& $\mathbf{2 0 0 6}$ & 1.591 & 1.982 & 2.688 \\
\hline
\end{tabular}

Source: Structure of Earnings Survey (SES).

Note: * Figures exclude some non-market sectors (educational, health, and social services) to obtain comparable figures with those for 1995.

5. Primary sector and domestic services are not covered by the survey.

6. Unfortunately, information about workers' nationality is not available in the 1995 wave. 
Figure 2 depicts in more detail some changes in the wage distributions. They show the raw gaps for men and women, respectively, distinguishing the two periods for which data are available. We subtract the log wage at a particular decile of the 1995 distribution from the corresponding log wage at that decile of the 2002 distribution (the same for the 2006 versus 2002 log wage distributions). Between 1995 and 2002 wages decreased by more at the low and medium deciles of the wage distribution, especially up to the $60^{\text {th }}$ percentile for males and $80^{\text {th }}$ for females. However, for the more recent period, the shape of wage changes along the wage distribution is quite different, with a slight wage increase at the low deciles and decreases for higher deciles for men. For women we observe increases in all percentiles except the highest one. Moreover, the fact that the difference between the deciles of the 2002 and 2006 log wage distributions is downward sloping indicates again the wage compression that took place between these two years.

Figure 2. Wage changes by deciles

Men

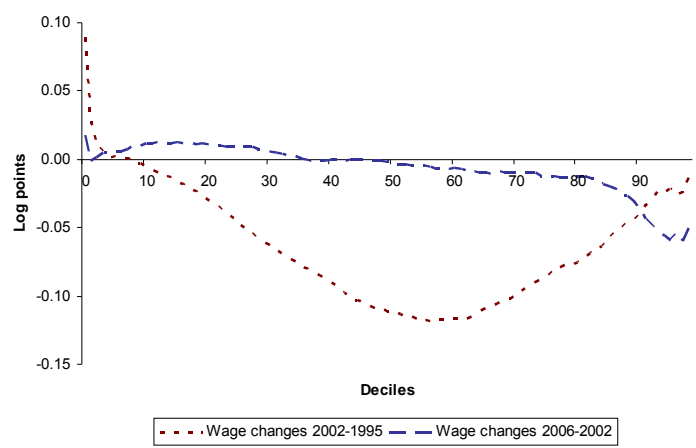

Women

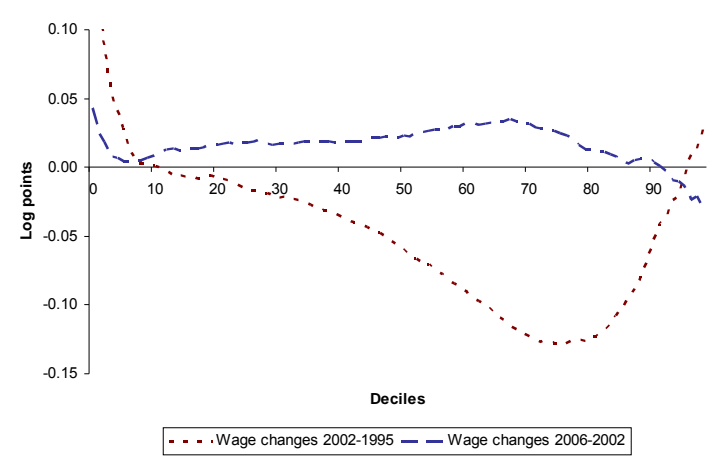




\section{Changes in the composition of employment and in wage gaps among some individual and job characteristics}

Observed wage changes are the combination of changes in the composition of workers and jobs, and changes in the wage differentials among workers and job characteristics. For many purposes, it is important to separate both sources of wage changes, particularly when some unusual changes in the composition of employment have taken place, as it was the case in Spain during the period 1995-2006.

The first important labour market development to take into account when interpreting changes in the Spanish wage distribution over this period is the variation in the gender composition of the labour force. Between 1995 and 2006, the proportion of women in the sample rose from $23.5 \%$ in 1995 to $36.4 \%$ and $40.5 \%$ in 2002 and 2006, respectively, while the gender wage gap decreased from 0.308 in 1995 to 0.234 and 0.212 log points, respectively, in 2002 and 2006. Whereas between 1995 and 2002 the gender wage gap decreased up to the $60^{\text {th }}$ percentile and increased for the upper tail of the distribution, in the period 2002-2006 the gender wage gap slightly decreased along the whole distribution (see Figure 3$)^{7}$. In the rest of the paper, we will follow a long-standing tradition in the analysis of the wage structure consisting of studying the male and the female wage distributions separately.

Figure 3. Changes in the gender wage gap

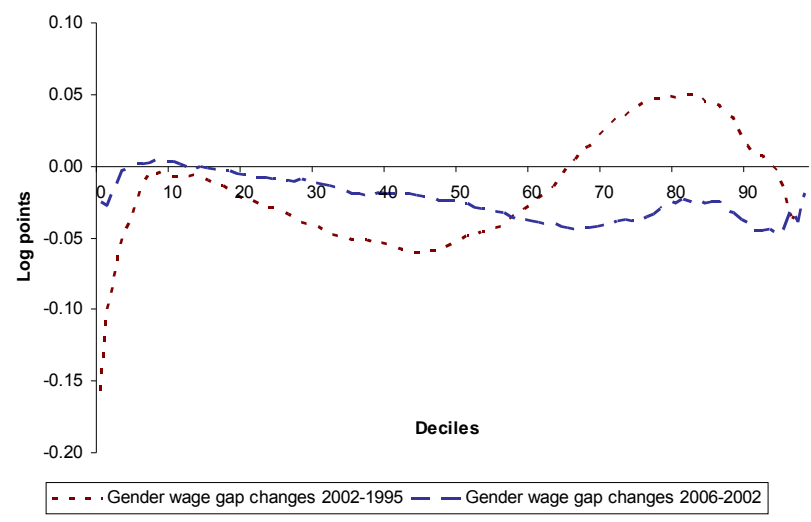

Other important labour supply development in Spain during this period was the increase in the educational level of workers, the occurrence of large immigration flows, and the ageing of the labour force (see Figure 4a). Thus, between 1995 and 2006 years of schooling rose by 0.8 for men and 1.2 for women and the weight of immigrants in the labour force grew from $2.7 \%$ to $6.2 \%$ for men and from $1.8 \%$ to $4.7 \%$ for women. In turn, between

7. Some recent studies on the gender wage gap in Spain are the following. De la Rica, Dolado and Llorens (2008), using data from the European Community Household Panel over the period 1994-2001, find that as in many other countries the gender gap for workers with high education increases over the distribution, but it is decreasing for workers with less education. Gardeázabal and Ugidos (2005), using the 1995 Structure of Earnings Survey, find that the raw gender gap increases along the distribution but that the discrimination component is larger at the bottom of the distribution. Similar results are found by García et al. (2001) using data from the 1991 Encuesta de Conciencia, Biografía y Estructura de Clase. 
2002 and 2006 the share of workers of more than 45 years of age increased from $27.1 \%$ to $29.8 \%$ for men and from $19.9 \%$ to $23.7 \%$ for men and women, respectively. It is also worth noticing that immigrants are more present in the lowest deciles (being around 5\% in 2002 and more than 10\% in 2006, in the case of men, and around 3\% in 2002 and $8 \%$ in 2006 in the case of women) and that the proportion of young workers in the three lowest deciles decreased between 1995 and 2006, while it increased for workers above 45 years of age. Despite the educational upgrading and the increase in workers average age, the proportion of workers with tenure below 3 years also increased between 1995 and 2006 by almost $13 \mathrm{pp}$ for men, and 9 p.p. for women, due to the high turnover created by the dual nature of the Spanish Employment Protection Legislation. ${ }^{8}$

As for labour demand, there have been also significant changes in compositions (see Figure 4b). As for occupations, there are clear signs of polarisation, as both high-skilled occupations (Professionals, Technicians) and low-skilled occupations (Administrative workers, Unskilled workers) increased their weight in total employment. As for the sectoral composition, the most noticeable changes are the increase in the weight of the construction sector, from 9.4\% of total male employment in 1995 to $12.2 \%$ and $13.2 \%$ in 2002 and 2006 , respectively, and the decrease of the weight of manufacturing in total male employment, from $17.8 \%$ in 1995 to $13.9 \%$ and $11.7 \%$ in 2002 and 2006 , respectively. ${ }^{9}$ In the case of women, there is an increasing trend in the weight of employment in the service sector. As for the segmentation between temporary and permanent employment, there seems to be no significant changes over this period, neither at the aggregate nor along different parts of the wage distribution.

8. See Dolado et al. (2002).

9. It is important to note that the 1995 survey does not cover some non-market sectors, such as education, health, and social services. When excluding these sectors of the other two years, the qualitative results basically hold. 
Figure 4a. Individual characteristics by deciles of the wage distribution

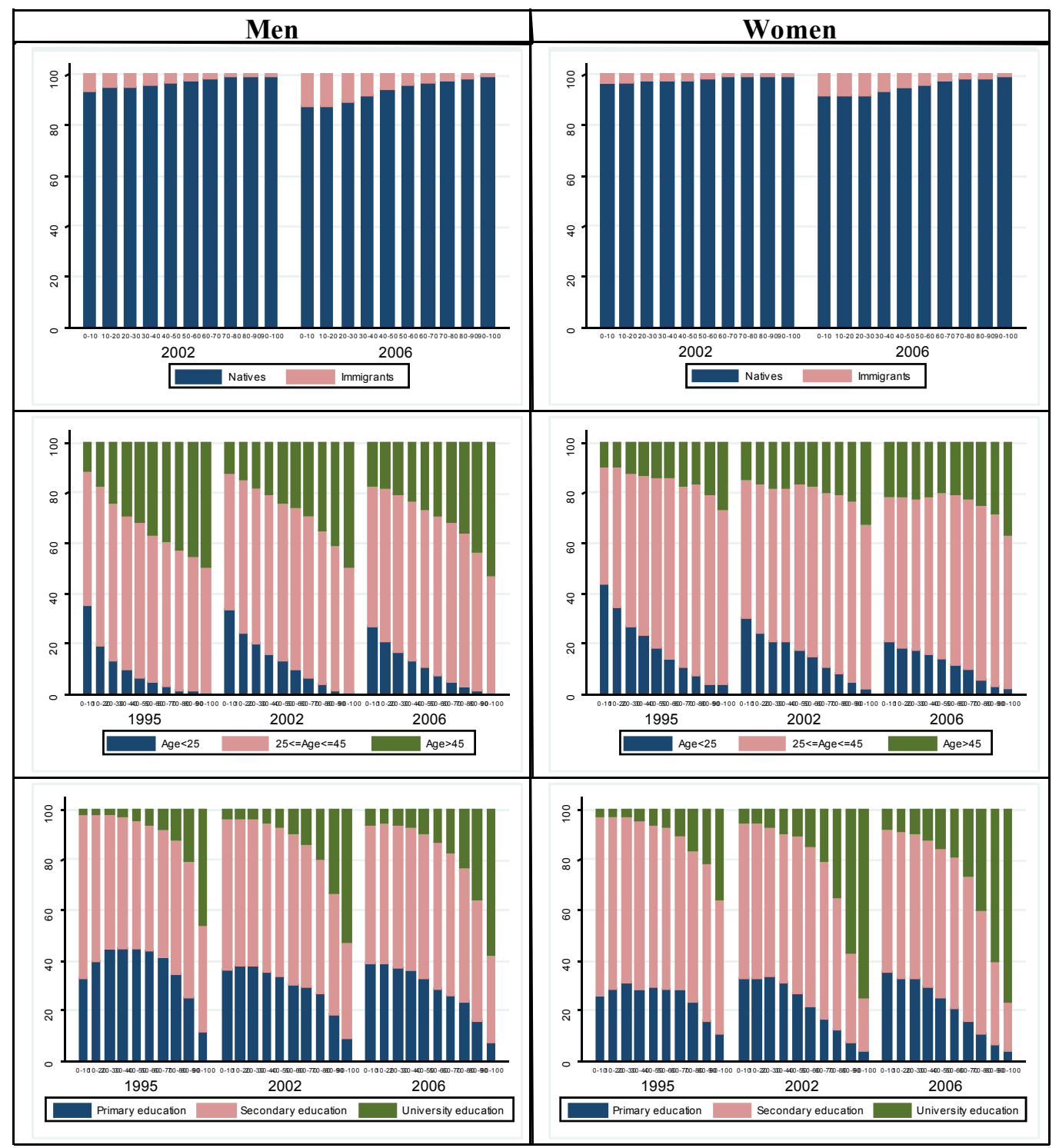


Figure 4b. Job characteristics by deciles of the wage distribution

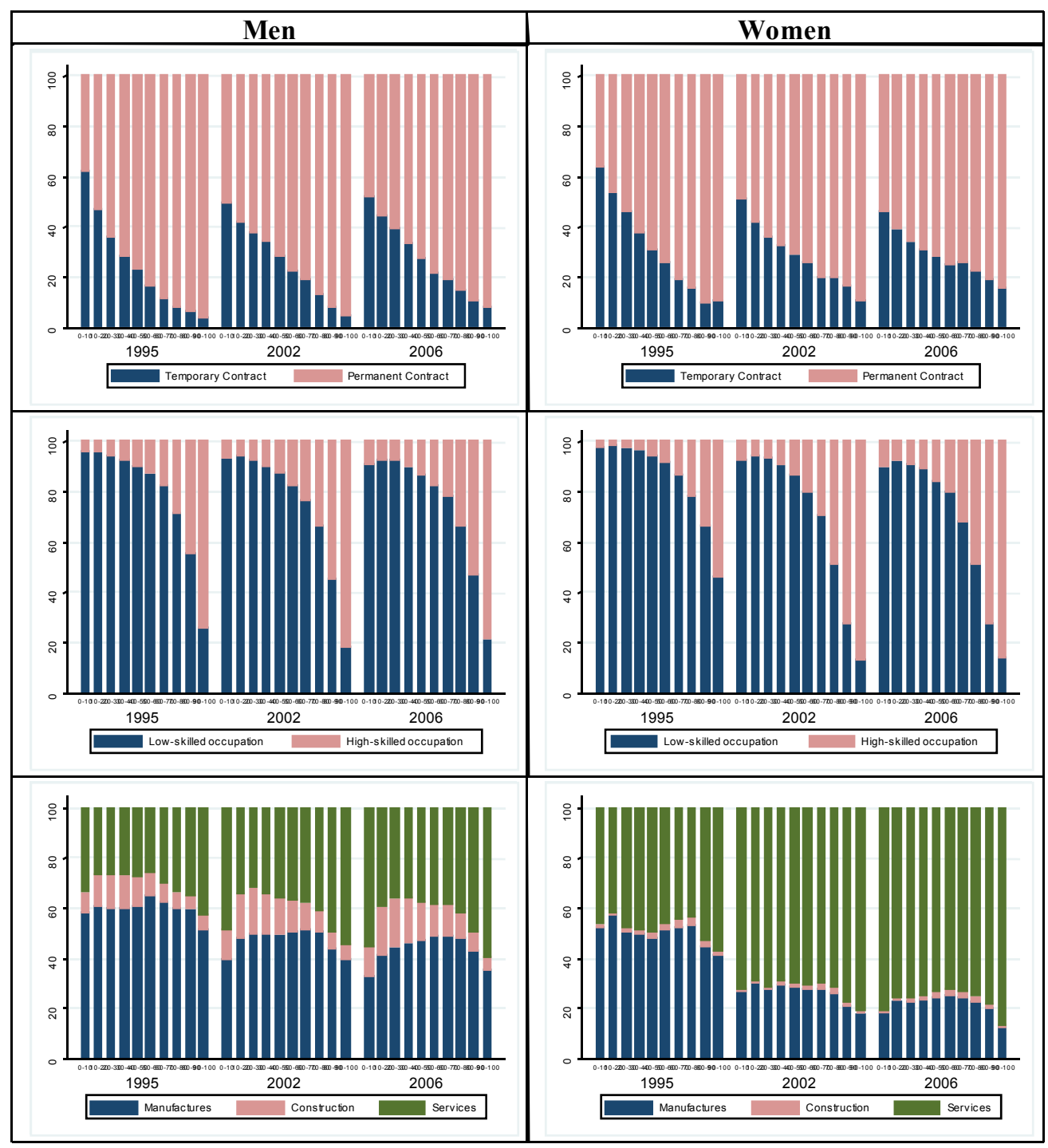


Figure 5 shows the changes in wage differentials among individual and jobs characteristics for each percentile of the wage distribution during the 1995-2002 and 2002-2006 periods. (For reference, in Figure A1 in the Appendix, we plot the levels of these differentials observed in 2006). As for the differentials between immigrant and natives, some recent papers [e.g. Adsera and Chiswick (2007)], using data from the European Community Household Panel, find a significant negative effect of immigrant status on individual earnings of around $40 \%$ at the time of arrival, although the difference is somewhat smaller for women. Earnings increase with duration in the destination country and the foreign-born "catch-up" to the native-born, others variables being the same, at around 18 years of residence. With the same data set, Peracchi and Depalo (2006) find that it takes to residing in the host country for $25+$ years to close the earnings gap relative to a native worker with similar characteristics. Simón, Sanromá and Ramos (2007) find that legal immigrants from developing countries exhibit lower mean wages and a more compressed wage structure than native-born workers, and that disparities in the wage distributions for native-born and immigrants are largely explained by their different observed characteristics, mostly due to occupational and workplace segregation. Canal-Domínguez and Rodríguez-Gutiérrez (2007) conclude that the unexplained component of the wage difference between native and immigrant workers has a decreasing behaviour along the wage distribution, even becoming negative at the end. They detect a remarkable wage difference against the group of immigrants with the lowest wages which is not explained by the differences in the productive features of native and immigrant workers. According to our data, the immigrant-native wage gap, which increases along the wage distribution (Figure A1, has increased at the top decile of the wage distribution between 2002 and 2006, and decreased in the lowest one, with minor changes in the rest of the distribution (Figure 5).

Differentials among educational groups are also sizeable [see Izquierdo and Lacuesta (2006) and Figure A1). Our data shows a decrease in the educational wage gap between those individuals with secondary and university education along the period 1995-2006 (Figure 5), which is more pronounced during the 1995-2002 period at the bottom deciles of the wage distribution. On the contrary, the wage gap between secondary and primary education has increased during the period 1995-2006 along the whole wage distribution. Wage differentials between high skilled workers and low skilled workers are also large and increasing along the wage distribution, as it is the case sectoral differences. However, in these dimensions, the most noticeable change during the 1995-2002 and 2002-2006 periods is the decrease of the high-low skill differential at the bottom and the increase at the top of the wage distribution during the former period, and the decrease, along the whole distribution, of the same differential and of the differential between sector services and manufacturing during the 2002-2006 period. As for wage differentials across workers age groups and employment contract status, the main changes are the decrease in youth relative wages during the 1995-2002 period and of the wage differential between permanent and temporary workers at the bottom of the distribution during 1995-2002 and at the top during 2002-2006. 
Figure 5. Wage gaps changes among some individual and job characteristics
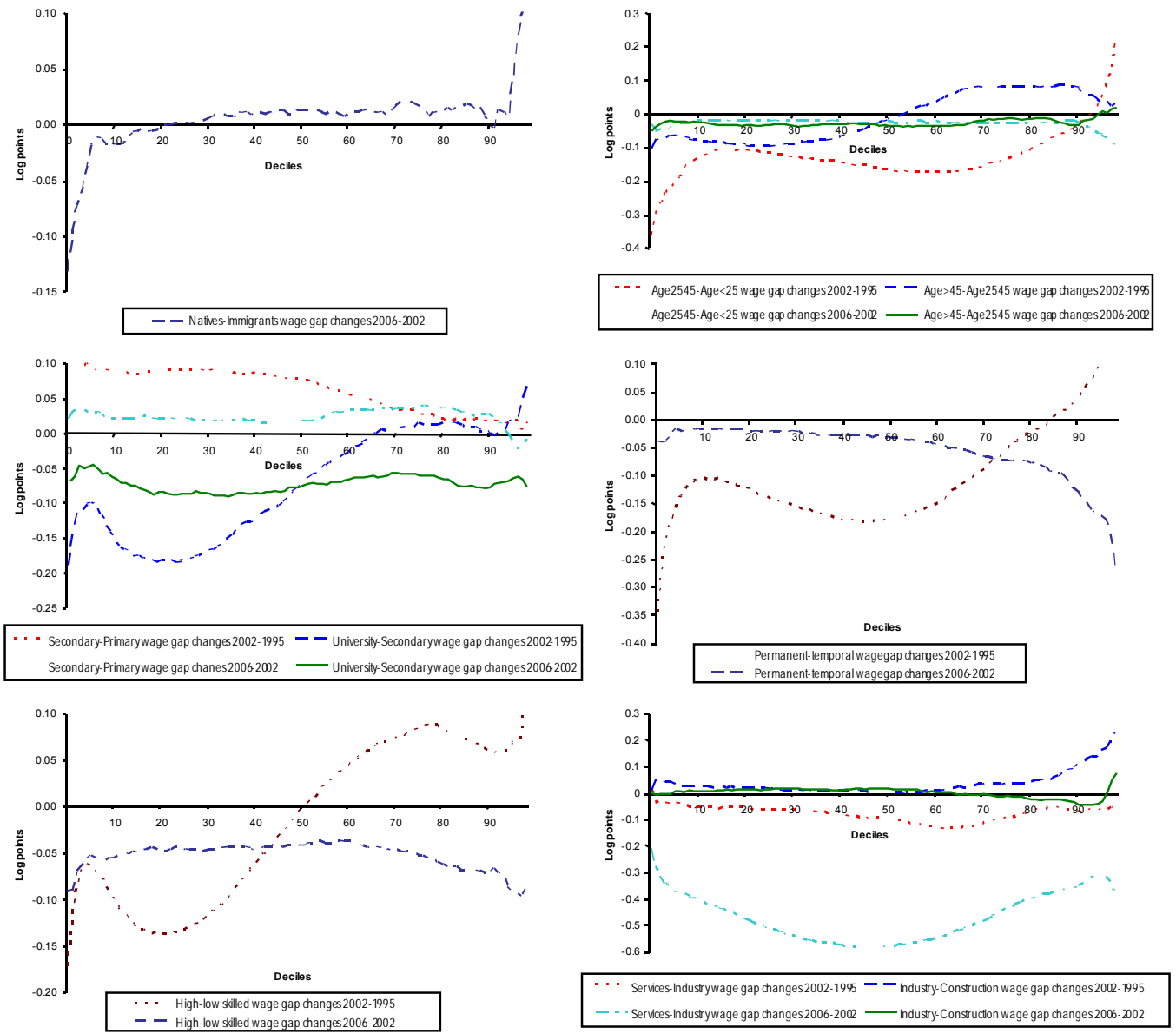


\section{A Decomposition of Changes in the Wage Distribution}

To account for the role of composition effects in wage changes, we construct counterfactual wage distributions that take into account that the relationship between wages and individual and job characteristics varies along the wage distribution. In a first step we perform quantile regressions $(\mathrm{QR})$ to obtain the distribution of log wages conditional on the covariates.

Following Koenker and Bassett (1978) and Buchinsky (1998), we assume that the $\theta$ th-order quantile of the log wage distribution in year $t$ conditional on characteristics is linear in those characteristics:

$$
Q^{\theta}\left(w_{t} \mid X_{t}=x_{t}\right)=\beta_{t}(\theta) x_{t}
$$

where $w_{t}$ and $x_{t}$ are, respectively, individual (log) wages and characteristics for year $t$ and $Q^{\theta}($. is the conditional $\theta$ th-order quantile of the distribution of wages given $x_{t}$. The parameters $\beta t(\theta)$ are estimated for different quantiles. Therefore, the quantile regression coefficients characterize the distribution of log wages each year conditional on characteristics.

We estimate quantile regressions separately for men and women, using two alternative specifications. In the first specification (model 1) only workers' age, age squared, years of schooling, and worker's nationality are included as regressors. For the comparison between 2002 and 20026, model 1 also includes a different constant for immigrants. Hence, under this specification the estimated wage differential is only purged-out of (exogenous) workers' characteristics. In the second specification (model 2) some job characteristics, such as tenure, occupation, and sector of activity are also included.

Tables $4 \mathrm{a}$ and $4 \mathrm{~b}$ present the quantile regression results for some percentiles (the $10^{\text {th }}, 50^{\text {th }}$, and $90^{\text {th }}$ ) for model $1 .^{10}$ We also present the estimated coefficients for the conditional mean of log wages (OLS estimates). The pattern showed in these tables points to positive returns to schooling which increases along the wage distribution for all years. Nonetheless, the returns to schooling have fallen over time, especially for men [see Felgueroso, Hidalgo and Jiménez-Martín (2010)]. When we include job characteristics among the regressors we find that the premium associated with schooling is lower. But it is still the case that the returns fall over time.

10. Estimates of model 2, which also includes job characteristics, are available upon request. 
Table 4a. OLS and QR. Model 1, Men

1995-2002

\begin{tabular}{|c|c|c|c|c|}
\hline & OLS & 0.1 & 0.5 & 0.9 \\
\hline \multicolumn{5}{|c|}{$1995(n=122,476)$} \\
\hline$\overline{\text { Age }}$ & $\begin{array}{c}0.080 \\
{[0.000]^{\star \star *}}\end{array}$ & $\begin{array}{c}0.061 \\
{[0.001]^{\star \star \star}}\end{array}$ & $\begin{array}{c}0.084 \\
{[0.001]^{\star \star \star}}\end{array}$ & $\begin{array}{c}0.088 \\
{[0.001]^{\star * *}}\end{array}$ \\
\hline $\operatorname{Age}^{\wedge} 2$ & $\begin{array}{l}-0.0007 \\
{[0.000]^{* \star \star}}\end{array}$ & $\begin{array}{l}-0.0006 \\
{[0.000]^{\star \star *}}\end{array}$ & $\begin{array}{l}-0.0008 \\
{[0.000]^{* \star *}}\end{array}$ & $\begin{array}{l}-0.0008 \\
{[0.000]^{* * *}}\end{array}$ \\
\hline Years of schooling & $\begin{array}{c}0.071 \\
{[0.000]^{\star * *}}\end{array}$ & $\begin{array}{c}0.049 \\
{[0.000]^{* \star *}}\end{array}$ & $\begin{array}{c}0.073 \\
{[0.000]^{* \star *}}\end{array}$ & $\begin{array}{c}0.077 \\
{[0.000]^{* \star *}}\end{array}$ \\
\hline Constant & $\begin{array}{c}-0.272 \\
{[0.016]^{\star \star \star}}\end{array}$ & $\begin{array}{l}-0.088 \\
{[0.021]^{\star \star *}}\end{array}$ & $\begin{array}{l}-0.387 \\
{[0.019]^{\star \star \star \star}}\end{array}$ & $\begin{array}{l}0.008 \\
{[0.030]}\end{array}$ \\
\hline \multicolumn{5}{|l|}{$2002(n=95,268 *)$} \\
\hline Age & $\begin{array}{c}0.044 \\
{[0.000]^{\star \star *}}\end{array}$ & $\begin{array}{c}0.030 \\
{[0.001]^{\star \star \star}}\end{array}$ & $\begin{array}{c}0.036 \\
{[0.001]^{\star \star \star *}}\end{array}$ & $\begin{array}{c}0.058 \\
{[0.001]^{\star \star \star}}\end{array}$ \\
\hline $\operatorname{Age}^{\wedge} 2$ & $\begin{array}{l}-0.0003 \\
{[0.000]^{\star \star *}}\end{array}$ & $\begin{array}{l}-0.0003 \\
{[0.000]^{* \star *}}\end{array}$ & $\begin{array}{l}-0.0002 \\
{[0.000]^{* \star *}}\end{array}$ & $\begin{array}{l}-0.000 \\
{[0.000]^{* * * *}}\end{array}$ \\
\hline Years of schooling & $\begin{array}{c}0.068 \\
{[0.000]^{\star \star \star}}\end{array}$ & $\begin{array}{c}0.035 \\
{[0.000]^{\star \star \star}}\end{array}$ & $\begin{array}{c}0.067 \\
{[0.000]^{* \star \star *}}\end{array}$ & $\begin{array}{c}0.079 \\
{[0.000]^{\star * *}}\end{array}$ \\
\hline Immigrant & $\begin{array}{c}-0.112 \\
{[0.008]^{\star \star *}}\end{array}$ & $\begin{array}{c}-0.099 \\
{[0.009]^{* \star *}}\end{array}$ & $\begin{array}{c}-0.083 \\
{[0.009]^{* \star *}}\end{array}$ & $\begin{array}{l}-0.101 \\
{[0.015]^{\star \star \star}}\end{array}$ \\
\hline Constant & $\begin{array}{c}0.447 \\
{[0.016]^{* * *}}\end{array}$ & $\begin{array}{c}0.728 \\
{[0.020]^{\star \star \star \star}}\end{array}$ & $\begin{array}{c}0.586 \\
{[0.019]^{* * *}}\end{array}$ & $\begin{array}{c}0.484 \\
{[0.034]^{\star \star \star *}}\end{array}$ \\
\hline
\end{tabular}

2002-2006

\begin{tabular}{|c|c|c|c|c|}
\hline & OLS & 0.1 & 0.5 & 0.9 \\
\hline \multicolumn{5}{|l|}{$2002(n=105,380)$} \\
\hline Age & $\begin{array}{c}0.045 \\
{[0.000]^{* * *}}\end{array}$ & $\begin{array}{c}0.031 \\
{[0.001]^{* \star *}}\end{array}$ & $\begin{array}{c}0.037 \\
{[0.001]^{* \star *}}\end{array}$ & $\begin{array}{c}0.058 \\
{[0.001]^{* * *}}\end{array}$ \\
\hline $\operatorname{Age}^{\wedge} 2$ & $\begin{array}{l}-0.0003 \\
{[0.000]^{* \star *}}\end{array}$ & $\begin{array}{c}-0.00033 \\
{[0.000]^{\star \star \star}}\end{array}$ & $\begin{array}{l}-0.0002 \\
{[0.000]^{\star * *}}\end{array}$ & $\begin{array}{l}-0.0004 \\
{[0.000]^{\star \star *}}\end{array}$ \\
\hline Years of schooling & $\begin{array}{c}0.067 \\
{[0.000]^{* \star \star}}\end{array}$ & $\begin{array}{c}0.038 \\
{[0.000]^{\star \star \star}}\end{array}$ & $\begin{array}{c}0.068 \\
{[0.000]^{\star \star \star}}\end{array}$ & $\begin{array}{c}0.077 \\
{[0.000]^{\star * *}}\end{array}$ \\
\hline Immigrant & $\begin{array}{l}-0.118 \\
{[0.008]^{* \star \star}}\end{array}$ & $\begin{array}{c}-0.109 \\
{[0.010]^{* \star \star}}\end{array}$ & $\begin{array}{l}-0.084 \\
{[0.009]^{* \star \star}}\end{array}$ & $\begin{array}{l}-0.112 \\
{[0.014]^{\star \star \star}}\end{array}$ \\
\hline Constant & $\begin{array}{c}0.440 \\
{[0.016]^{* \star \star}}\end{array}$ & $\begin{array}{c}0.649 \\
{[0.021]^{\star \star \star}}\end{array}$ & $\begin{array}{c}0.541 \\
{[0.019]^{\star \star \star}}\end{array}$ & $\begin{array}{c}0.515 \\
{[0.031]^{\star \star \star}}\end{array}$ \\
\hline \multicolumn{5}{|l|}{$2006(n=104,252)$} \\
\hline Age & $\begin{array}{c}0.039 \\
{[0.000]^{* \star \star}}\end{array}$ & $\begin{array}{c}0.030 \\
{[0.001]^{\star \star \star *}}\end{array}$ & $\begin{array}{c}0.035 \\
{[0.000]^{* \star *}}\end{array}$ & $\begin{array}{c}0.049 \\
{[0.001]^{\star * *}}\end{array}$ \\
\hline $\operatorname{Age}^{\wedge} 2$ & $\begin{array}{l}-0.0003 \\
{[0.000]^{\star * \star}}\end{array}$ & $\begin{array}{l}-0.0003 \\
{[0.000]^{\star \star *}}\end{array}$ & $\begin{array}{l}-0.0002 \\
{[0.000]^{* \star *}}\end{array}$ & $\begin{array}{l}-0.0003 \\
{[0.000]^{\star * *}}\end{array}$ \\
\hline Years of schooling & $\begin{array}{c}0.056 \\
{[0.000]^{\star \star \star}}\end{array}$ & $\begin{array}{c}0.030 \\
{[0.000]^{\star \star \star}}\end{array}$ & $\begin{array}{c}0.056 \\
{[0.000]^{\star \star \star *}}\end{array}$ & $\begin{array}{c}0.065 \\
{[0.000]^{\star * \star}}\end{array}$ \\
\hline Immigrant & $\begin{array}{l}-0.128 \\
{[0.005]^{\star \star \star \star}}\end{array}$ & $\begin{array}{c}-0.105 \\
{[0.007]^{\star \star \star}}\end{array}$ & $\begin{array}{l}-0.110 \\
{[0.006]^{* \star \star}}\end{array}$ & $\begin{array}{l}-0.100 \\
{\left[0.0096^{* \star *}\right.}\end{array}$ \\
\hline Constant & $\begin{array}{c}0.690 \\
{[0.016]^{\star \star \star}}\end{array}$ & $\begin{array}{c}0.782 \\
{[0.021]^{\star \star \star}}\end{array}$ & $\begin{array}{c}0.742 \\
{[0.018]^{\star \star \star}}\end{array}$ & $\begin{array}{c}0.809 \\
{[0.030]^{\star * \star}}\end{array}$ \\
\hline
\end{tabular}

Source: Structure of Earnings Survey, 1995, 2002 and 2006.

Standard errors are in parenthesis. ${ }^{\star \star \star}$ means statistically significant at a $1 \%$ level, ** means statistically significant at a $5 \%$ level and * means statistically significant at a 10\% level. 
Table 4b. OLS and QR. Model 1, Women

1995-2002

\begin{tabular}{|c|c|c|c|c|}
\hline & OLS & 0.1 & 0.5 & 0.9 \\
\hline \multicolumn{5}{|l|}{$1995(n=37,564)$} \\
\hline Age & $\begin{array}{c}0.069 \\
{[0.001]^{\star \star \star *}}\end{array}$ & $\begin{array}{c}0.064 \\
{[0.001]^{\star \star \star}}\end{array}$ & $\begin{array}{c}0.067 \\
{[0.001]^{\star \star *}}\end{array}$ & $\begin{array}{c}0.079 \\
{[0.002]^{\star \star \star}}\end{array}$ \\
\hline $\operatorname{Age}^{\wedge} 2$ & $\begin{array}{l}-0.0007 \\
{[0.000]^{\star \star \star}}\end{array}$ & $\begin{array}{l}-0.0007 \\
{[0.000]^{* \star \star}}\end{array}$ & $\begin{array}{l}-0.0006 \\
{[0.000]^{\star \star *}}\end{array}$ & $\begin{array}{l}-0.0007 \\
{[0.000]^{\star \star \star}}\end{array}$ \\
\hline Years of schooling & $\begin{array}{c}0.068 \\
{[0.000]^{* \star *}}\end{array}$ & $\begin{array}{c}0.048 \\
{[0.000]^{* \star \star}}\end{array}$ & $\begin{array}{c}0.070 \\
{[0.000]^{\star \star \star}}\end{array}$ & $\begin{array}{c}0.074 \\
{[0.001]^{\star \star \star}}\end{array}$ \\
\hline Constant & $\begin{array}{c}-0.193 \\
{[0.026]^{\star \star *}}\end{array}$ & $\begin{array}{l}-0.245 \\
{[0.036]^{* \star \star}}\end{array}$ & $\begin{array}{l}-0.212 \\
{[0.030]^{* \star *}}\end{array}$ & $\begin{array}{r}-0.001 \\
{[0.051]} \\
\end{array}$ \\
\hline \multicolumn{5}{|l|}{$2002\left(n=43,707^{*}\right)$} \\
\hline Age & $\begin{array}{c}0.042 \\
{[0.001]^{\star \star \star *}}\end{array}$ & $\begin{array}{c}0.026 \\
{[0.001]^{\star \star \star}}\end{array}$ & $\begin{array}{c}0.035 \\
{[0.001]^{\star \star \star}}\end{array}$ & $\begin{array}{c}0.052 \\
{[0.002]^{\star \star \star}}\end{array}$ \\
\hline $\operatorname{Age}^{\wedge} 2$ & $\begin{array}{l}-0.0004 \\
{[0.000]^{* \star *}}\end{array}$ & $\begin{array}{l}-0.0003 \\
{[0.000]^{* * *}}\end{array}$ & $\begin{array}{l}-0.0003 \\
{[0.000]^{\star \star \star}}\end{array}$ & $\begin{array}{l}-0.0004 \\
{[0.000]^{\star \star *}}\end{array}$ \\
\hline Years of schooling & $\begin{array}{c}0.064 \\
{[0.000]^{\star \star *}}\end{array}$ & $\begin{array}{c}0.033 \\
{[0.000]^{* * *}}\end{array}$ & $\begin{array}{c}0.058 \\
{[0.000]^{\star \star *}}\end{array}$ & $\begin{array}{c}0.083 \\
{[0.001]^{* \star \star \star}}\end{array}$ \\
\hline Immigrant & $\begin{array}{c}-0.071 \\
{[0.013]^{\star * *}}\end{array}$ & $\begin{array}{l}-0.085 \\
{[0.017]^{* \star \star}}\end{array}$ & $\begin{array}{l}-0.046 \\
{[0.015]^{\star \star \star}}\end{array}$ & $\begin{array}{l}-0.067 \\
{[0.029]^{\star \star}}\end{array}$ \\
\hline Constant & $\begin{array}{c}0.390 \\
{[0.023]^{\star \star *}}\end{array}$ & $\begin{array}{c}0.696 \\
{[0.030]^{* \star \star}}\end{array}$ & $\begin{array}{c}0.569 \\
{[0.028]^{\star \star *}}\end{array}$ & $\begin{array}{c}0.361 \\
{[0.057]^{* \star * \star}}\end{array}$ \\
\hline
\end{tabular}

2002-2006

\begin{tabular}{|c|c|c|c|c|}
\hline & OLS & 0.1 & 0.5 & 0.9 \\
\hline \multicolumn{5}{|l|}{$2002(n=60,343)$} \\
\hline Age & $\begin{array}{c}0.042 \\
{[0.001]^{\star \star \star *}}\end{array}$ & $\begin{array}{c}0.029 \\
{[0.001]^{* \star *}}\end{array}$ & $\begin{array}{c}0.038 \\
{[0.001]^{* \star \star}}\end{array}$ & $\begin{array}{c}0.051 \\
{[0.002]^{\star * *}}\end{array}$ \\
\hline $\operatorname{Age}^{\wedge} 2$ & $\begin{array}{l}-0.0004 \\
{[0.000]^{\star \star *}}\end{array}$ & $\begin{array}{l}-0.0003 \\
{[0.000]^{\star \star \star}}\end{array}$ & $\begin{array}{l}-0.0003 \\
{[0.000]^{\star \star \star}}\end{array}$ & $\begin{array}{l}-0.0004 \\
{[0.000]^{* * *}}\end{array}$ \\
\hline Years of schooling & $\begin{array}{c}0.075 \\
{[0.000]^{* * *}}\end{array}$ & $\begin{array}{c}0.043 \\
{[0.000]^{* \star \star}}\end{array}$ & $\begin{array}{c}0.077 \\
{[0.000]^{\star \star \star}}\end{array}$ & $\begin{array}{c}0.086 \\
{[0.001]^{* \star *}}\end{array}$ \\
\hline Immigrant & $\begin{array}{l}-0.067 \\
{[0.012]^{\star \star \star}}\end{array}$ & $\begin{array}{c}-0.089 \\
{[0.016]^{* * *}}\end{array}$ & $\begin{array}{c}-0.043 \\
{[0.014]^{* \star \star}}\end{array}$ & $\begin{array}{c}-0.063 \\
{[0.023]^{\star \star \star}}\end{array}$ \\
\hline Constant & $\begin{array}{c}0.240 \\
{[0.020]^{\star \star *}}\end{array}$ & $\begin{array}{c}0.487 \\
{[0.027]^{\star \star *}}\end{array}$ & $\begin{array}{c}0.274 \\
{[0.024]^{\star \star \star}}\end{array}$ & $\begin{array}{c}0.363 \\
{[0.042]^{\star \star *}}\end{array}$ \\
\hline \multicolumn{5}{|l|}{$2006(n=71,049)$} \\
\hline Age & $\begin{array}{c}0.032 \\
{[0.001]^{\star \star *}}\end{array}$ & $\begin{array}{c}0.021 \\
{[0.001]^{\star \star \star}}\end{array}$ & $\begin{array}{c}0.029 \\
{[0.001]^{\star \star \star}}\end{array}$ & $\begin{array}{c}0.043 \\
{[0.001]^{* * *}}\end{array}$ \\
\hline $\operatorname{Age}^{\wedge} 2$ & $\begin{array}{l}-0.0003 \\
{[0.000]^{\star * *}}\end{array}$ & $\begin{array}{l}-0.0002 \\
{[0.000]^{* \star}}\end{array}$ & $\begin{array}{l}-0.0002 \\
{[0.000]^{\star \star \star}}\end{array}$ & $\begin{array}{l}-0.0004 \\
{[0.000]^{* * *}}\end{array}$ \\
\hline Years of schooling & $\begin{array}{c}0.063 \\
{\left[0.0004^{* * *}\right.}\end{array}$ & $\begin{array}{c}0.035 \\
{[0.000]^{* \star \star}}\end{array}$ & $\begin{array}{c}0.065 \\
{[0.000]^{\star \star \star}}\end{array}$ & $\begin{array}{c}0.074 \\
{[0.000]^{\star * *}}\end{array}$ \\
\hline Immigrant & $\begin{array}{l}-0.083 \\
{[0.007]^{\star \star *}}\end{array}$ & $\begin{array}{c}-0.067 \\
{[0.009]^{\star \star \star}}\end{array}$ & $\begin{array}{l}-0.074 \\
{[0.009]^{\star \star \star}}\end{array}$ & $\begin{array}{c}-0.075 \\
{[0.012]^{\star \star \star}}\end{array}$ \\
\hline Constant & $\begin{array}{c}0.568 \\
{[0.020]^{\star \star \star}}\end{array}$ & $\begin{array}{c}0.741 \\
{[0.026]^{\star \star \star}}\end{array}$ & $\begin{array}{c}0.587 \\
{[0.025]^{\star \star \star}}\end{array}$ & $\begin{array}{c}0.687 \\
{[0.038]^{\ldots \star \star}}\end{array}$ \\
\hline
\end{tabular}

Source: Structure of Earnings Survey, 1995, 2002 and 2006.

Standard errors are in parenthesis. ${ }^{* *}$ means statistically significant at a $1 \%$ level, ${ }^{* *}$ means statistically significant at a $5 \%$ level and * means statistically significant at a $10 \%$ level. 
We use the estimated quantile regression coefficients for 1995, 2002, and 2006 to simulate counterfactual distributions that can be used to decompose differences in distributions. That is, we want to analyze to what extent we can account for the observed gap between the 2002 and 1995 and between the 2006 and 2002 distributions by changes in the distribution of observables and returns to those observables.

For that purpose, we use the method of Machado and Mata (2005). The decomposition is based on the construction of wages that would have prevailed in 2002 (2006) if the distribution of characteristics had been as in 1995 (2002). The steps in the algorithm to construct them are as follows:

(i) Estimate $\beta t(\theta)$ for a grid of values $\theta=0.01,0.02,0.99$ for year $t=2$.

(ii) Multiply each estimated quantile regression coefficient by each $X$ in year 1 's empirical distribution of observables. This generates $\mathrm{N}^{*} \mathrm{~m}$ fitted values, $\hat{w}\left(\hat{\beta}_{2}, X_{1}\right)$, where $\mathrm{N}$ is the size of the year I sample and $m=99$ is the number of quantiles estimated in the first step.

(iii) Randomly select $\mathrm{s}=100$ of the elements of $\hat{w}\left(\hat{\beta}_{2}, X_{1}\right)$ for each $\theta$ and stack these into a $99 \times 100$ element vector. The empirical c.d.f. of these values is the estimated counterfactual distribution.

Thus, the differences in wages at each quantile can be breakdown as follows:

$$
\hat{w}\left(\hat{\beta}_{2}, X_{2}\right)-\hat{w}\left(\hat{\beta}_{1}, X_{1}\right)=\left[\hat{w}\left(\hat{\beta}_{2}, X_{2}\right)-\hat{w}\left(\hat{\beta}_{2}, X_{1}\right)\right]+\left[\hat{w}\left(\hat{\beta}_{2}, X_{1}\right)-\hat{w}\left(\hat{\beta}_{1}, X_{1}\right)\right]
$$

where the first bracket represents the effects of changes in the distribution of covariates, and the second the effects of changes in coefficients. 


\section{$5 \quad$ Results}

Figure 6 (and Table 6) presents the main results of the empirical exercise described above. Each graph contains the observed wage changes along the whole wage distribution for the two periods, 1995-2002 and 2002-2006 (solid lines), and the two components of these changes, that due to the changes in the composition of employment (dotted lines) and that due to the changes in the returns to those characteristics (dashed lines). Separate results are shown for men and women and, also, from wage regressions in which only worker characteristics (age, years of schooling and nationality status) are considered as determinants of wages (Model 1), and from wage regressions in which job characteristics (occupation sector, contract status, and tenure) are also included as covariates (Model 2).

Regarding the changes in the male wage distribution, there is some contrast between the period 1995-2002, with wage decreases along the wage distribution, except for the first decile and with a lower decrease at the upper percentiles respect to those observed in the middle part of the distribution, and the period 2002-2006, where wages remained more or less constant below the median, and decreased to a larger extent in the upper decile.

As for the wage changes due to composition effects, in the 1995-2002 period there is a noticeable difference between composition effects accounted only for individual characteristics (Model 1) and composition effects accounted both for individual and job characteristics (Model 2). During this period, individual characteristics improved, so that wages would have increased other things equal, while job characteristics worsened, pushing wages downwards. In contrast, for the period between 2002 and 2006, the decomposition of wage changes into characteristics and returns do not vary much between both models, that is, changes in job characteristics, overall, did not affect much the changes in the wage distribution, which suggest that the main compositional effects in wage changes during the most recent period is due to education and labour market experience. A common result across both periods and models is that the improvements in individual and job characteristics are larger at the upper deciles, while returns to individual characteristics, decreased more markedly also at the upper deciles, so that the improvement in worker characteristics did not translate into increasing wages.

As far as women are concerned, results are qualitatively similar to those obtained for men. Observed wage changes were only negative for the 1995-2002 period and in the middle-upper part of the wage distribution, while were close to zero for the 2002-2006 period. The improvement of personal characteristics took place at the upper deciles of the distribution in both periods, and was significantly lower in the period 1995-2002 when job characteristics are also taken into account (except for the upper decile). Both across models and periods, returns to characteristics decrease noticeable in the upper deciles of the wage distribution.

Overall, these results confirm that changes in employment composition cannot fully explain the dismal performance of Spanish wages over this period. To this regard, the comparison between wage changes at some deciles of the wage distribution and the wage changes that would have been observed have individual and individual/job characteristics remained constant (the solid and the dashed lines of Graphs in Figure 6) is quite illustrative. Both for men and women, the effects of changes in individual characteristics on wages 
are not very relevant, except for the upper quatile, where individual characteristics improved, so that real wages would have fallen by more had those characteristics remain constant. When changes in job characteristics are also taken into account, the same happens, with the only modification that during the period 1995-2002 wages would have not fallen in the first three deciles of the wage distribution had worker and job characteristics remain constant. Thus, the idea that employment composition effects are the main factor explaining the fall of real wages get some support, in the case of male wages, only for the period 1995-2002.

Hence, despite the rise of the weight of immigrants in employment and of low-skills occupations in labour intensive sectors (such as construction and personal services), other individual characteristics, notably educational level and labour market experience (as approximated by age) more than compensated for the negative composition effects of the former variables on wages. It is only the decrease of the returns to education and labour market experience, and to some extent, worsening of job characteristics over 1995-2002, what can explain why Spanish real wages decreased during the 1995-2002 period and barely increased during the 2002-2006. ${ }^{11}$

Figure 6. Breakdown of wage changes by deciles

Men

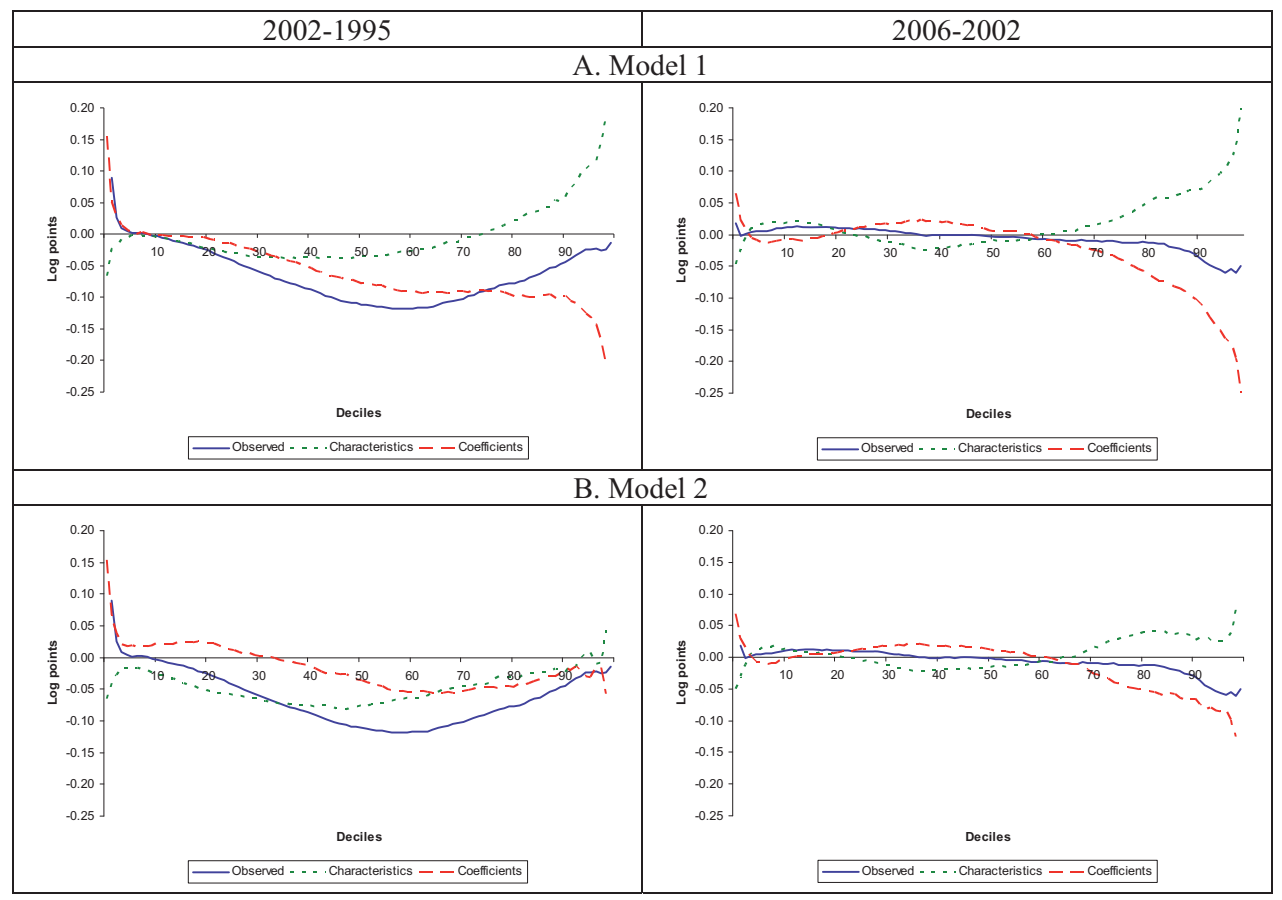

11. Regarding decreasing returns to education, our results are in line with those of previous studies who have looked specifically to the wage returns to education in Spain. De la Fuente and Jimeno (2009) show that Spain is one of the countries where returns to education are lower in Europe. For further evidence of decreasing returns to education in Spain, see Izquierdo and Lacuesta (2006) and Lacuesta Puente and Cuadrado (forthcoming). 
Figure 6 (continued)

\section{Women}

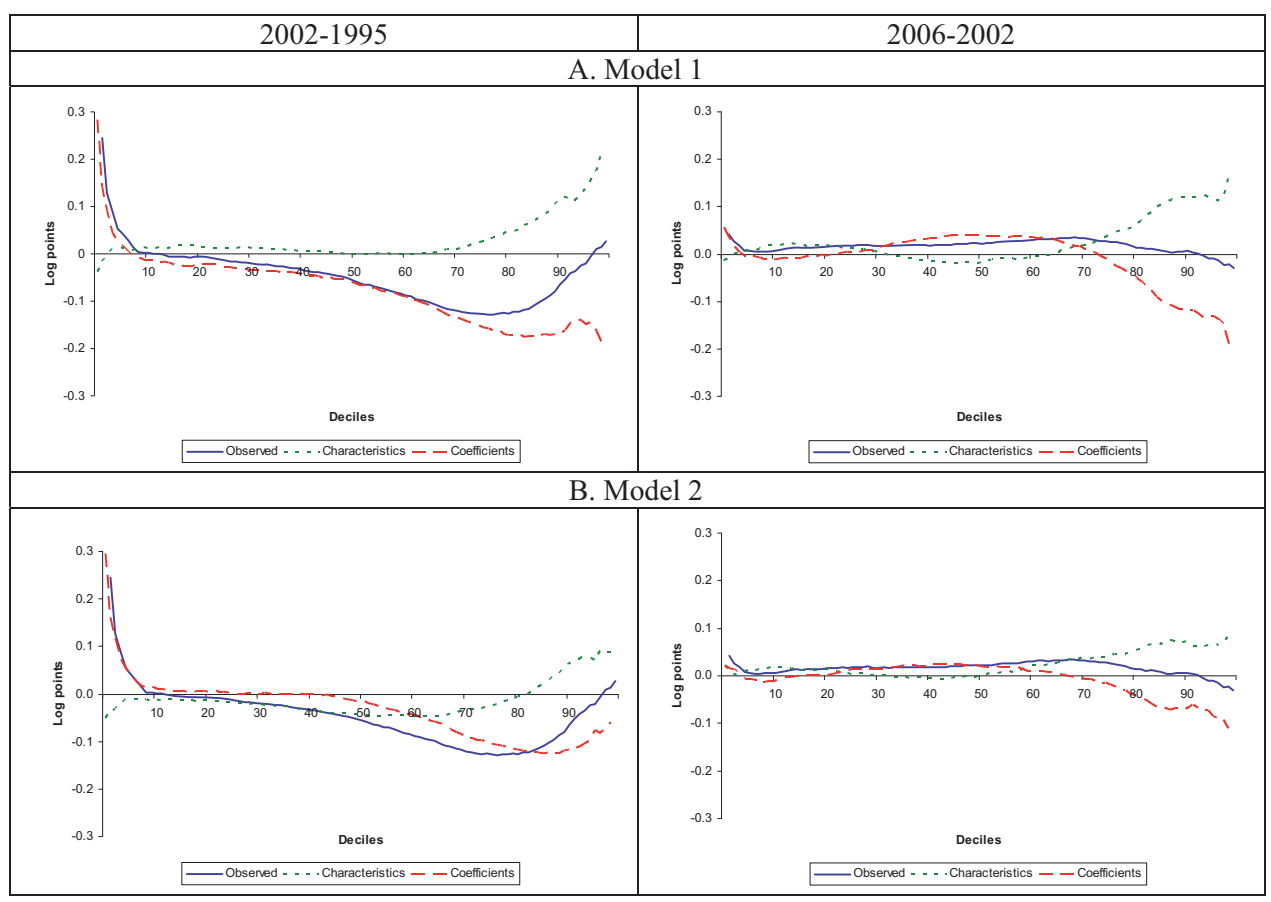

Table 5. Observed wage changes and counterfactual wage changes (for constant worker and job characteristics)

\begin{tabular}{|c|c|c|c|c|c|}
\hline 2002-1995. Men & $\theta=10$ & $\theta=25$ & $\theta=50$ & $\theta=75$ & $\theta=90$ \\
\hline Observed 2002-1995 change (\%) & -0.294 & -4.301 & -11.106 & -8.792 & -4.496 \\
\hline $\begin{array}{l}\text { (Model 1) Counterfactual 2002-1995 } \\
\text { change (\%) }\end{array}$ & -0.088 & -1.354 & -7.473 & -8.820 & -9.820 \\
\hline $\begin{array}{lll}\begin{array}{l}\text { (Model 2) } \\
\text { change (\%) }\end{array} & \text { Counterfactual 2002-1995 } \\
\end{array}$ & 2.007 & 1.362 & -3.370 & -4.615 & -2.574 \\
\hline 2006-2002. Men & $\theta=10$ & $\theta=25$ & $\theta=50$ & $\theta=75$ & $\theta=90$ \\
\hline Observed 2006-2002 change (\%) & 0.01050 & 0.009440 & -0.00209 & -0.01188 & -0.0385 \\
\hline $\begin{array}{l}\text { (Model 1) Counterfactual 2006-2002 } \\
\text { change (\%1) }\end{array}$ & -0.79 & 1.129 & 0.743 & -3.686 & -10.165 \\
\hline $\begin{array}{lll}\begin{array}{l}\text { (Model 2) } \\
\text { change (\%) }\end{array} & \text { Counterfactual } 2006-2002 \\
\end{array}$ & -0.215 & 1.217 & -0.209 & -1.188 & -3.085 \\
\hline 2002-1995. Women & $\theta=10$ & $\theta=25$ & $\theta=50$ & $\theta=75$ & $\theta=90$ \\
\hline Observed 2002-1995 change (\%) & 1.49 & -1.403 & -5.676 & -12.752 & -6.603 \\
\hline $\begin{array}{l}\text { (Model 1) Counterfactual 2002-1995 } \\
\text { change (\%) }\end{array}$ & -1.197 & -2.654 & -5.659 & -15.099 & -10.699 \\
\hline $\begin{array}{l}\text { (Model 2) } \\
\text { change (\%) }\end{array}$ & 1.464 & 0.317 & -1.447 & -10.146 & -11.897 \\
\hline 2006-2002. Women & $\theta=10$ & $\theta=25$ & $\theta=50$ & $\theta=75$ & $\theta=90$ \\
\hline Observed 2006-2002 change (\%) & 0.695 & 1.810 & 2.143 & 2.634 & 0.675 \\
\hline $\begin{array}{l}(\text { Model 1) Counterfactual 2006-2002 } \\
\text { change (\%)) }\end{array}$ & -1.136 & 0.456 & 4.000 & -0.941 & -11.396 \\
\hline $\begin{array}{lll}\begin{array}{l}\text { (Model 2) } \\
\text { change (\%) }\end{array} & \text { Counterfactual 2006-2002 } \\
\end{array}$ & -1.044 & 1.270 & 2.281 & -1.488 & -6.326 \\
\hline
\end{tabular}




\section{Concluding remarks}

This paper analyses the contribution of changes in employment composition along several dimensions (individual and job characteristics) to the observed changes in the Spanish wage distribution over the period 1995-2006. During this period, mean real hourly wages barely changed, and wage dispersion remained almost constant, having fallen in the lower half of the distribution and risen in the upper half.

By breaking-down observed wage changes at each decile of the wage distribution in two terms related to changes in the distribution of workers and jobs characteristics and changes in returns to those characteristics, we provide a very detail account of the sources of changes in aggregate and relative wages for the periods 1995-2002 and 2002-2006 for which microeconomic data from the three waves of Structure of Earnings Survey (1995, 2002 and 2006) are available. Over the full period, employment composition effects derived from changes in education levels and experience (as approximated by age) of Spanish employees had no effects at roughly the first three quartiles and had a positive effect on real wages at the last quartile of the wage distribution, while changes in job characteristics explain lower real wages, only in the case of men during the period 1995-2002.

Thus, our results show that the idea that employment composition effects are the main factor that explain the dismal performance of Spanish real wages over this period get only mild support. To a larger extent, it is the fall in returns to some individual characteristics, remarkably education and experience, what causes the lack of growth of wages. The fact that labour market mismatch is a pervasive phenomenon in Spain as far as university graduates is concerned [see Dolado, Jansen and Jimeno (2009)], is another indication of the problems of the Spanish economy to generate high-productivity jobs for highly educated worker. This problem may have two causes, one related to labour supply, one related to labour demand. As for the labour supply, a deficient educational system, able to deliver large number of highly educated workers, may not be producing the adequate skills to be matched with high productivity jobs. As for labour demand, the dual nature of Employment Protection Legislation in Spain and the very high worker turnover rates that it creates, may not be the best environment for young highly educated workers to capitalize on their skills. 
Appendix

Table A1. Sample means (standard deviations in cursive)

\begin{tabular}{|c|c|c|c|c|c|c|c|c|}
\hline & \multicolumn{2}{|c|}{1995} & \multicolumn{2}{|c|}{2002 (excludes non-market sectors) } & \multicolumn{2}{|c|}{2002} & \multicolumn{2}{|c|}{2006} \\
\hline & Men & Women & Men & Women & Men & Women & Men & Women \\
\hline \multirow[t]{2}{*}{ Log Hourly Wage } & 2.4036 & 2.0956 & 2.343 & 2.052 & 2.3596 & 2.1253 & 2.3535 & 2.1415 \\
\hline & 0.5250 & 0.4838 & 0.510 & 0.448 & 0.5186 & 0.4901 & 0.5017 & 0.4831 \\
\hline \multirow[t]{2}{*}{ Age } & 39.7488 & 34.7412 & 38.027 & 35.195 & 38.1543 & 36.0583 & 39.1217 & 37.3484 \\
\hline & 10.9184 & 9.8542 & 11.001 & 10.035 & 10.9498 & 10.1629 & 11.0483 & 10.3362 \\
\hline \multirow[t]{2}{*}{ Years of schooling } & 10.0291 & 10.5429 & 10.477 & 10.898 & 10.7402 & 11.5940 & 10.8388 & 11.7384 \\
\hline & 3.2000 & 2.9867 & 3.217 & 3.284 & 3.3892 & 3.5179 & 3.7612 & 3.8411 \\
\hline \multirow[t]{2}{*}{ Immigrant } & & & 0.029 & 0.020 & 0.0275 & 0.0176 & 0.0617 & 0.0470 \\
\hline & & & 0.167 & 0.140 & 0.1636 & 0.1314 & 0.2406 & 0.2115 \\
\hline \multirow[t]{2}{*}{ Tenure $\leq 3$ years } & 0.3090 & 0.4009 & 0.453 & 0.545 & 0.4477 & 0.5179 & 0.4338 & 0.4873 \\
\hline & 0.4621 & 0.4901 & 0.498 & 0.498 & 0.4973 & 0.4997 & 0.4956 & 0.4998 \\
\hline \multirow[t]{2}{*}{ Part-time } & 0.0162 & 0.1064 & 0.032 & 0.226 & 0.0451 & 0.2199 & 0.0664 & 0.2771 \\
\hline & 0.1262 & 0.3084 & 0.177 & 0.418 & 0.2075 & 0.4142 & 0.2489 & 0.4476 \\
\hline \multirow[t]{2}{*}{ Temporary Contract } & 0.2427 & 0.3134 & 0.257 & 0.277 & 0.2587 & 0.2836 & 0.2707 & 0.2850 \\
\hline & 0.4287 & 0.4639 & 0.437 & 0.447 & 0.4379 & 0.4507 & 0.4443 & 0.4514 \\
\hline \multirow[t]{2}{*}{ Professionals } & 0.1012 & 0.0525 & 0.082 & 0.053 & 0.1136 & 0.1493 & 0.1176 & 0.1642 \\
\hline & 0.3016 & 0.2231 & 0.274 & 0.223 & 0.3174 & 0.3564 & 0.3221 & 0.3705 \\
\hline \multirow[t]{2}{*}{ Technicians } & 0.1074 & 0.0938 & 0.134 & 0.155 & 0.1381 & 0.1492 & 0.1350 & 0.1473 \\
\hline & 0.3096 & 0.2915 & 0.341 & 0.362 & 0.3450 & 0.3563 & 0.3417 & 0.3544 \\
\hline \multirow[t]{2}{*}{ Administrative workers } & 0.1015 & 0.3161 & 0.076 & 0.216 & 0.0758 & 0.1840 & 0.0831 & 0.1933 \\
\hline & 0.3020 & 0.4650 & 0.265 & 0.411 & 0.2647 & 0.3875 & 0.2760 & 0.3949 \\
\hline \multirow[t]{2}{*}{ Services and trade workers } & 0.0604 & 0.1190 & 0.073 & 0.177 & 0.0756 & 0.1941 & 0.0620 & 0.1985 \\
\hline & 0.2382 & 0.3238 & 0.261 & 0.382 & 0.2643 & 0.3955 & 0.2411 & 0.3989 \\
\hline \multirow[t]{2}{*}{ Skilled manual workers } & 0.2401 & 0.0900 & 0.261 & 0.053 & 0.2405 & 0.0392 & 0.2575 & 0.0477 \\
\hline & 0.4271 & 0.2862 & 0.439 & 0.224 & 0.4274 & 0.1940 & 0.4373 & 0.2132 \\
\hline Machinery operators & 0.2742 & 0.1649 & 0.265 & 0.131 & 0.2462 & 0.0986 & 0.2150 & 0.0667 \\
\hline & 0.4461 & 0.3711 & 0.442 & 0.337 & 0.4308 & 0.2982 & 0.4108 & 0.2495 \\
\hline Unskilled workers & 0.1152 & 0.1637 & 0.109 & 0.216 & 0.1101 & 0.1857 & 0.1298 & 0.1823 \\
\hline & 0.3193 & 0.3700 & 0.311 & 0.412 & 0.3130 & 0.3889 & 0.3361 & 0.3861 \\
\hline Extraction industries & 0.0192 & 0.0038 & 0.019 & 0.003 & 0.0169 & 0.0024 & 0.0148 & 0.0025 \\
\hline & 0.1373 & 0.0614 & 0.135 & 0.057 & 0.1289 & 0.0486 & 0.1206 & 0.0500 \\
\hline Manufactures & 0.1783 & 0.2747 & 0.153 & 0.197 & 0.1385 & 0.1427 & 0.1171 & 0.1100 \\
\hline & 0.3827 & 0.4464 & 0.360 & 0.398 & 0.3455 & 0.3498 & 0.3215 & 0.3128 \\
\hline Chemical manufacturing & 0.1333 & 0.0912 & 0.110 & 0.065 & 0.0995 & 0.0472 & 0.0981 & 0.0408 \\
\hline & 0.3399 & 0.2879 & 0.313 & 0.247 & 0.2994 & 0.2120 & 0.2974 & 0.1978 \\
\hline Metal manufacturing & 0.1459 & 0.0713 & 0.143 & 0.052 & 0.1289 & 0.0377 & 0.1217 & 0.0341 \\
\hline & 0.3531 & 0.2574 & 0.350 & 0.222 & 0.3351 & 0.1904 & 0.3270 & 0.1815 \\
\hline Other manufacturing & 0.0874 & 0.0462 & 0.076 & 0.039 & 0.0689 & 0.0284 & 0.0650 & 0.0243 \\
\hline & 0.2824 & 0.2100 & 0.265 & 0.194 & 0.2533 & 0.1661 & 0.2465 & 0.1541 \\
\hline Electricity, water and gas & 0.0339 & 0.0135 & 0.022 & 0.009 & 0.0200 & 0.0066 & 0.0184 & 0.0058 \\
\hline & 0.1809 & 0.1154 & 0.147 & 0.095 & 0.1399 & 0.0808 & 0.1343 & 0.0762 \\
\hline Construction & 0.0938 & 0.0211 & 0.135 & 0.020 & 0.1223 & 0.0147 & 0.1323 & 0.0169 \\
\hline & 0.2916 & 0.1438 & 0.342 & 0.141 & 0.3276 & 0.1203 & 0.3388 & 0.1288 \\
\hline Trade & 0.0780 & 0.1628 & 0.092 & 0.181 & 0.0836 & 0.1308 & 0.0877 & 0.1372 \\
\hline & 0.2681 & 0.3692 & 0.290 & 0.385 & 0.2768 & 0.3372 & 0.2828 & 0.3441 \\
\hline Hotels and restaurants & 0.0443 & 0.1099 & 0.046 & 0.127 & 0.0419 & 0.0922 & 0.0401 & 0.0839 \\
\hline & 0.2058 & 0.3128 & 0.210 & 0.333 & 0.2004 & 0.2892 & 0.1961 & 0.2772 \\
\hline Transports & 0.0642 & 0.0470 & 0.072 & 0.044 & 0.0655 & 0.0320 & 0.0724 & 0.0359 \\
\hline & 0.2451 & 0.2116 & 0.259 & 0.205 & 0.2474 & 0.1759 & 0.2591 & 0.1862 \\
\hline Financial activities & 0.0759 & 0.0827 & 0.055 & 0.066 & 0.0501 & 0.0478 & 0.0466 & 0.0485 \\
\hline & 0.2649 & 0.2754 & 0.229 & 0.248 & 0.2181 & 0.2133 & 0.2108 & 0.2148 \\
\hline Real state & 0.0458 & 0.0758 & 0.075 & 0.196 & 0.0680 & 0.1421 & 0.0821 & 0.1598 \\
\hline & 0.2090 & 0.2647 & 0.264 & 0.397 & 0.2517 & 0.3491 & 0.2746 & 0.3665 \\
\hline Non-market sectors & & & & & 0.0960 & 0.2757 & 0.1038 & 0.3003 \\
\hline & & & & & 0.2945 & 0.4469 & 0.3050 & 0.4584 \\
\hline Number of observations & 122,476 & 37,564 & 95,268 & 43,707 & 105,380 & 60,343 & 104,252 & 71,049 \\
\hline
\end{tabular}


Figure A1. Wage gaps among some individual and job characteristics, 2006

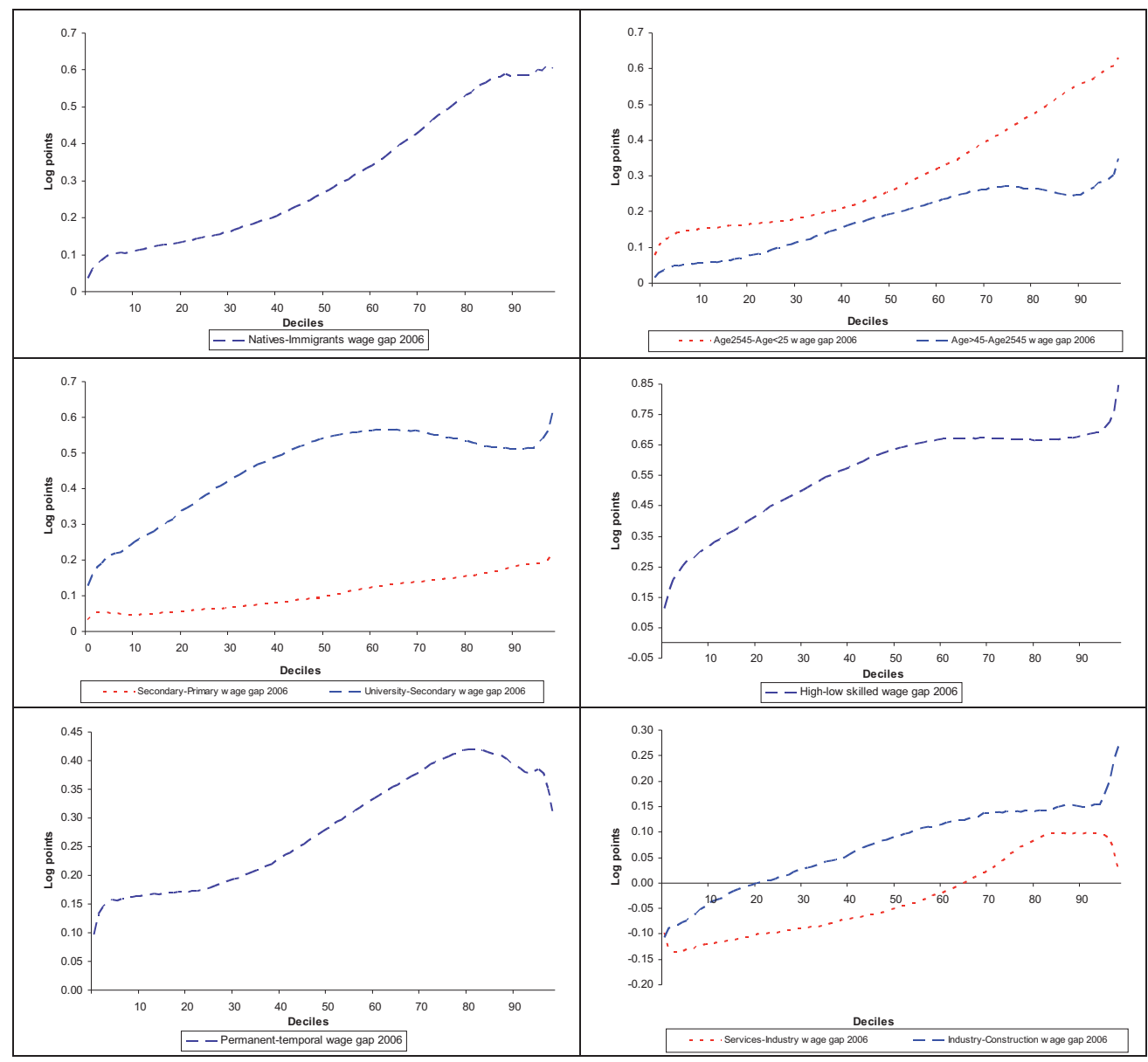




\section{REFERENCES}

ADSERA, A., and B. CHISWICK (2007). "Are There Gender and Country of Origin Differences in Immigrant Labor Market Outcomes across European Destinations?", Journal of Population Economics, in press.

ALBRECHT, J., A. BJÖRKLUND and S. VROMAN (2003). "Is There a Glass Ceiling in Sweden?", Journal of Labor Economics, Vol. 21, No. 11, pp. 145-177.

- (2010). "Unionization and the Evolution of the Wage Distribution in Sweden: 1968 to 2000", Industrial and Labor Relations Review, in press.

ARCE, O., J. M. CAMPA and A. GAVILÁN (2009). Asymmetric collateral requirements and output composition, Working Paper No. 0837, Banco de España.

ARULAMPALAM, W., A. L. BOOTH and M. L. BRYAN (2007). "Is There a Glass Ceiling over Europe? Exploring the Gender Pay Gap across the Wage Distribution", Industrial and Labor Relations Review, Vol. 60, No. 2, January, pp. 163-186.

BOVER, O., and M. ARELLANO (1995), "Female labour force participation in the 1980s: the case of Spain", Investigaciones Económicas, Vol. 19 (2), May, pp. 171-194.

BUCHINSKY, M. (1994). "Changes in the U.S. wage structure 1963-1987: Application of quantile regression", Econometrica, Vol. 62, pp. 405-458.

CANAL-DOMÍNGUEZ, J. F., and C. RODRÍGUEZ-GUTIÉRREZ (2007). "Analysis of Wage Differences between native and Immigrant Workers in Spain", Spanish Economic Review, forthcoming.

CARRASCO, R., J. F. JIMENO and A. C. ORTEGA (2008). "The Effect of Immigration on the Labour Market Performance of Native-Born Workers: Some Evidence for Spain”, Journal of Population Economics, 21 (3), pp. 627-648.

CHRISTOPOULOU, R., J. F. JIMENO and A. LAMO (2010). "Changes in the Wage Structure in EU Countries", Working Paper No. 1017, Banco de Espana. Available at SSRN: http://ssrn.com/abstract=1628603.

DE LA FUENTE, A., and J. F. JIMENO (2009). "The private and fiscal returns to schooling in the EU", Journal of the European Economic Association, 7 (6), December, pp.1-30.

DE LA RICA, S., J. J. DOLADO and V. LLORENS (2008). "Ceilings or Floors?: Gender Wage Gaps by Education in Spain", Journal of Population Economics, Vol. 20 (3), pp. 751-776.

DOLADO, J. J., C. GARCÍA-SERRANO and J. F. JIMENO (2002). "Drawing lessons from the boom of temporary jobs in Spain", The Economic Journal, 112 (480), June, pp. F270-F295.

FELGUEROSO, F., M. HIDALGO and S. JIMÉNEZ-MARTÍN (2010). Explaining the fall of the skill wage premium in Spain, Documento de Trabajo 2010-19, Fedea.

GARDEAZÁBAL, J., and A. UGIDOS (2005). "Gender Wage Discrimination at Quantiles", Journal of Population Economics, 18, pp 165-179.

GONZÁLEZ, L., and F. ORTEGA (2009). "How Do Very Open Economies Absorb Large Immigration Flows? Evidence from Spanish Regions", Labour Economics, forthcoming.

IZQUIERDO, M., and A. LACUESTA (2006). Wage inequality in Spain: Recent Developments, Documentos de Trabajo, No. 0615, Banco de España.

KOENKER, R., and G. BASSETT (1978). "Regression Quantiles", Econometrica, 46, pp. 33-50.

LACUESTA, A., S. PUENTE and P. CUADRADO (forthcoming). "Omitted Variables in the Measurement of Labour Quality Index: The case of Spain", Review of Income and Wealth.

MACHADO, J. A. F., and J. MATA (2005). "Counterfactual Decomposition of Changes in Wage Distibutions using Quantile Regression", Journal of Applied Econometrics, Vol. 20, pp. 445-465.

MARTÍNEZ-SANCHÍS, E., J. MORA and I. KANDEMIR (2011). Counterfactual distributions of wages via quantile regression with endogeneity.

MELLY, B. (2005). "Decomposition of differences in distribution using quantile regression", Labour Economics, 12 , pp. 577-590.

OECD (2007). Employment Outlook, OECD, Paris

ORRENIUS, P. M., and M. ZAVODNY (2003). Does Immigration Affect Wages? A Look at Occupation-Level Evidence, Working Paper No. 0302, Federal Reserve Bank of Dallas.

OTTAVIANO, G., and G. PERI (2006). Rethinking the effects of Immigration on Wages, NBER Working Paper 12497.

PERACCHI, F., and D. DEPALO (2006). Labor market outcomes of natives and immigrants: Evidence from the ECHP, mimeo.

PIJOAN-MAS, J., and V. SÁNCHEZ-MARCOS (2010). "Spain is different: Falling trends of inequality", Review of Economic Dynamics, 13, pp. 154-178.

SIMÓN, H., E. SANROMÁ and R. RAMOS (2007). Labour Segregation and Immigrant and Native-born Wage Distributions in Spain: An Analysis Using Matched Employer-Employee Data, mimeo. 


\section{BANCO DE ESPAÑA PUBLICATIONS}

\section{WORKING PAPERS ${ }^{1}$}

1001 JAVIER ANDRÉS, ÓSCAR ARCE AND CARLOS THOMAS: Banking competition, collateral constraints and optimal monetary policy.

1002 CRISTINA BARCELÓ AND ERNESTO VILLANUEVA: The response of household wealth to the risk of losing the job: evidence from differences in firing costs.

1003 ALEXANDER KARAIVANOV, SONIA RUANO, JESÚS SAURINA AND ROBERT TOWNSEND: No bank, one bank, several banks: does it matter for investment?

1004 GABRIEL PEREZ-QUIROS AND HUGO RODRÍGUEZ MENDIZÁBAL: Asymmetric standing facilities: an unexploited monetary policy tool.

1005 GABRIEL JIMÉNEZ, JOSE A. LOPEZ AND JESÚS SAURINA: How does competition impact bank risk-taking?

1006 GIUSEPPE BERTOLA, AURELIJUS DABUSINSKAS, MARCO HOEBERICHTS, MARIO IZQUIERDO, CLAUDIA KWAPIL, JEREMI MONTORNÈS AND DANIEL RADOWSKI: Price, wage and employment response to shocks: evidence from the WDN Survey.

1007 JAVIER MENCÍA: Testing non-linear dependence in the Hedge Fund industry.

1008 ALFREDO MARTíN-OLIVER: From proximity to distant banking: Spanish banks in the EMU.

1009 GALO NUÑO: Optimal research and development expenditure: a general equilibrium approach.

1010 LUIS J. ÁLVAREZ AND PABLO BURRIEL: Is a Calvo price setting model consistent with micro price data?

1011 JENS HAGENDORFF, IGNACIO HERNANDO, MARÍA J. NIETO AND LARRY D. WALL: What do premiums paid for bank M\&As reflect? The case of the European Union.

1012 DAVID DE ANTONIO LIEDO: General equilibrium restrictions for dynamic factor models.

1013 JAMES COSTAIN, JUAN F. JIMENO AND CARLOS THOMAS: Employment fluctuations in a dual labor market.

1014 LUIS M. VICEIRA AND RICARDO GIMENO: The euro as a reserve currency for global investors.

1015 PALOMA LÓPEZ-GARCÍA AND JOSÉ MANUEL MONTERO: Understanding the Spanish business innovation gap: The role of spillovers and firms' absorptive capacity.

1016 AITOR LACUESTA AND SERGIO PUENTE: El efecto del ciclo económico en las entradas y salidas de inmigrantes en España.

1017 REBEKKA CHRISTOPOULOU, JUAN F. JIMENO AND ANA LAMO: Changes in the wage structure in EU countries.

1018 THOMAS BREUER, MARTIN JANDAČKA, JAVIER MENCÍA AND MARTIN SUMMER: A systematic approach to multi-period stress testing of portfolio credit risk.

1019 LUIS J. ÁLVAREZ AND PABLO BURRIEL: Micro-based estimates of heterogeneous pricing rules: The United States vs. the euro area.

1020 ALFREDO MARTÍN-OLIVER AND VICENTE SALAS-FUMÁS: I.T. investment and intangibles: Evidence from banks.

1021 LUISA LAMBERTINI, CATERINA MENDICINO AND MARIA TERESA PUNZI: Expectations-driven cycles in the housing market.

1022 JULIÁN MESSINA, PHILIP DU CAJU, CLÁUDIA FILIPA DUARTE, NIELS LYNGGÅRD HANSEN AND MARIO IZQUIERDO: The incidence of nominal and real wage rigidity: an individual-based sectoral approach.

1023 ALESSIO MORO: Development, growth and volatility.

1024 LUIS J. ÁLVAREZ AND ALBERTO CABRERO: Does housing really lead the business cycle?

1025 JUAN S. MORA-SANGUINETTI: Is judicial inefficiency increasing the house property market weight in Spain? Evidence at the local level.

1026 MAXIMO CAMACHO, GABRIEL PEREZ-QUIROS AND PILAR PONCELA: Green shoots in the Euro area. A real time measure.

1027 AITOR ERCE AND JAVIER DÍAZ-CASSOU: Creditor discrimination during sovereign debt restructurings.

1028 RAFAEL REPULLO, JESÚS SAURINA AND CARLOS TRUCHARTE: Mitigating the pro-cyclicality of Basel II.

1029 ISABEL ARGIMÓN AND JENIFER RUIZ: The effects of national discretions on banks.

1030 GABRIEL JIMÉNEZ, STEVEN ONGENA, JOSÉ-LUIS PEYDRÓ AND JESÚS SAURINA: Credit supply: identifying balance-sheet channels with loan applications and granted loans.

1031 ENRIQUE MORAL-BENITO: Determinants of economic growth: A Bayesian panel data approach.

1. Previously published Working Papers are listed in the Banco de España publications catalogue. 
1032 GABE J. DE BONDT, TUOMAS A. PELTONEN AND DANIEL SANTABÁRBARA: Booms and busts in China's stock market: Estimates based on fundamentals.

1033 CARMEN MARTÍNEZ-CARRASCAL AND JULIAN VON LANDESBERGER: Explaining the demand for money by nonfinancial corporations in the euro area: A macro and a micro view.

1034 CARMEN MARTíNEZ-CARRASCAL: Cash holdings, firm size and access to external finance. Evidence for the euro area.

1035 CÉSAR ALONSO-BORREGO: Firm behavior, market deregulation and productivity in Spain.

1036 OLYMPIA BOVER: Housing purchases and the dynamics of housing wealth.

1037 DAVID DE ANTONIO LIEDO AND ELENA FERNÁNDEZ MUÑOZ: Nowcasting Spanish GDP growth in real time: "One and a half months earlier".

1038 FRANCESCA VIANI: International financial flows, real exchange rates and cross-border insurance.

1039 FERNANDO BRONER, TATIANA DIDIER, AITOR ERCE AND SERGIO L. SCHMUKLER: Gross capital flows: dynamics and crises.

1101 GIACOMO MASIER AND ERNESTO VILLANUEVA: Consumption and initial mortgage conditions: evidence from survey data.

1102 PABLO HERNÁNDEZ DE COS AND ENRIQUE MORAL-BENITO: Endogenous fiscal consolidations.

1103 CÉSAR CALDERÓN, ENRIQUE MORAL-BENITO AND LUIS SERVÉN: Is infrastructure capital productive? A dynamic heterogeneous approach.

1104 MICHAEL DANQUAH, ENRIQUE MORAL-BENITO AND BAZOUMANA OUATTARA: TFP growth and its determinants: nonparametrics and model averaging.

1105 JUAN CARLOS BERGANZA AND CARMEN BROTO: Flexible inflation targets, forex interventions and exchange rate volatility in emerging countries.

1106 FRANCISCO DE CASTRO, JAVIER J. PÉREZ AND MARTA RODRÍGUEZ VIVES: Fiscal data revisions in Europe.

1107 ANGEL GAVILÁN, PABLO HERNÁNDEZ DE COS, JUAN F. JIMENO AND JUAN A. ROJAS: Fiscal policy, structural reforms and external imbalances: a quantitative evaluation for Spain.

1108 EVA ORTEGA, MARGARITA RUBIO AND CARLOS THOMAS: House purchase versus rental in Spain.

1109 ENRIQUE MORAL-BENITO: Dynamic panels with predetermined regressors: likelihood-based estimation and Bayesian averaging with an application to cross-country growth.

1110 NIKOLAI STÄHLER AND CARLOS THOMAS: FiMod - a DSGE model for fiscal policy simulations.

1111 ÁLVARO CARTEA AND JOSÉ PENALVA: Where is the value in high frequency trading?

1112 FILIPA SÁ AND FRANCESCA VIANI: Shifts in portfolio preferences of international investors: an application to sovereign wealth funds.

1113 REBECA ANGUREN MARTÍN: Credit cycles: Evidence based on a non-linear model for developed countries.

1114 LAURA HOSPIDO: Estimating non-linear models with multiple fixed effects: A computational note.

1115 ENRIQUE MORAL-BENITO AND CRISTIAN BARTOLUCCI: Income and democracy: Revisiting the evidence.

1116 AGUSTÍN MARAVALL HERRERO AND DOMINGO PÉREZ CAÑETE: Applying and interpreting model-based seasonal adjustment. The euro-area industrial production series.

1117 JULIO CÁCERES-DELPIANO: Is there a cost associated with an increase in family size beyond child investment? Evidence from developing countries.

1118 DANIEL PÉREZ, VICENTE SALAS-FUMÁS AND JESÚS SAURINA: Do dynamic provisions reduce income smoothing using loan loss provisions?

1119 GALO NUÑO, PEDRO TEDDE AND ALESSIO MORO: Money dynamics with multiple banks of issue: evidence from Spain 1856-1874.

1120 RAQUEL CARRASCO, JUAN F. JIMENO AND A. CAROLINA ORTEGA: Accounting for changes in the Spanish wage distribution: the role of employment composition effects.

\section{BANCODEESPAÑA}

Eurosistema
Unidad de Publicaciones

Alcalá 522, 28027 Madrid

Telephone +3491338 6363. Fax +34913386488

E-mail: publicaciones@bde.es www.bde.es 